\title{
Sod production and the effects of liquid organo-mineral fertilizers and
}

\section{thickness of sod}

\author{
Claudinei Paulo de Lima ${ }^{1}$, Clarice Backes², Alessandro José Marques Santos², Roberto Lyra Villas Bôas ${ }^{3}$, Dirceu Maximino Fernandes ${ }^{3}$, \\ Leandro José Grava de Godoy ${ }^{*}$, Mauricio Roberto de Oliveira ${ }^{3}$
}

Integrated Colleges of Ourinhos - Dept. of Agronomy, Rod. BR 153, km 338 - 19909-100 - Ourinhos, SP - Brazil. ${ }^{2}$ State University of Goiás - Dept. of Animal Science, R. da Saudade, 56 - 76100-000 - São Luís de Montes Belos, GO - Brazil.

${ }^{3}$ São Paulo State University/FCA - Dept. of Soils and Environmental Resources, R. José Barbosa de Barros, 1780 - 18610-307 - Botucatu, SP - Brazil.

${ }^{4}$ São Paulo State University - Dept. of Agronomy, Av. Nelson Brihi Badur, 430 - 11900-000 - Registro, SP - Brazil.

*Corresponding author <legodoy@registro.unesp.br>

Edited by: Francesco Montemurro

Received August 11, 2016

Accepted April 04, 2017
ABSTRACT: Nitrogen fertilization and an appropriate cutting thickness can result in firmer sod that can be handled in less time with greater turfgrass regrowth during the subsequent cycle. This experiment was conducted on a sod production farm located in Capela do Alto, in the state of Sao Paulo, Brazil. The soil was a dystrophic Rhodic Hapludox (Oxisol) with a medium texture. The experiment had two statistical designs; the initial design was randomized blocks with seven treatments and four replicates. Treatments were five doses of liquid organo-mineral fertilizer (OMF) corresponding to $0,100,200,300$ and $400 \mathrm{~kg} \mathrm{ha}^{-1}$ of nitrogen (N) with supplementation of phosphorous (P) and potassium (K) as well as two control treatments - one with $300 \mathrm{~kg}$ ha-1 of $\mathrm{N}$ as OMF and the other with $300 \mathrm{~kg} \mathrm{ha}^{-1}$ of $\mathrm{N}$-urea $+\mathrm{P}$ and $\mathrm{K}$. At harvest, the adopted design was a split-plot type with four replicates in a $7 \times 3$ factorial arrangement with seven treatments as the main plot and three sod cutting heights $(9,16$ and $22 \mathrm{~mm})$ as subplots. Nitrogen doses in the form of OMF influenced the percentage of ground cover (PGC) by turfgrass in both cycles. The $\mathrm{N}$ dose of $300 \mathrm{~kg} \mathrm{ha}^{-1}$ formed the sod more quickly and provided the largest mass of roots and stolons and the highest sod tensile strength. The thinnest sod samples had faster regrowth and provided higher PGCs.

Keywords: Zoysia japonica Steud., nitrogen fertilization, sod quality

\section{Introduction}

Although not among the world's leading turfgrass producers, Brazil has a growing turfgrass production sector. Zoysiagrass cv. Esmeralda is the species used in the majority of Brazilian residential gardens and is also frequently used for slope stabilization in areas with potential erosion problems (Dinalli et al., 2015). Zoysiagrass cv. Esmeralda (Zoysia japonica Steud.) adapts widely to Brazilian conditions. It is commonly used as an ornamental turfgrass in residential and industrial areas and in the surroundings comprising roads and highways.

Nutrition and fertilization influence the quality and time of turf growth rate during sod production. Turfgrass with adequate nitrogen $(\mathrm{N})$ has the fastest shoot growth (Bowman et al., 2002), which reduces the time required for the production of sod, which is the main form of turfgrass sale in Brazil. However, excess of $\mathrm{N}$ causes excessive leaf growths, increasing mowing expenses (Gazola et al., 2016), reducing root growth and decreasing the tensile strength of sod (Lima et al., 2010), and thereby reducing its quality.

Cutting thickness is an important factor because it is related to sod quality (liftability). In the Brazilian market, there is no standardization of sod thickness because it varies depending on soil type, soil moisture, formation of roots, rhizomes and stolons, soil compaction level and market demand.

Fertilization may represent $24 \%$ of the cost of sod production (Falconer and Niemeyer, 2006). Thus, alternatives that minimize such costs are of great interest to producers. A liquid organo-mineral fertilizer (OMF) has been used in sod production in São Paulo State. It is a byproduct of the food industry that can be used as a source of $\mathrm{N}$. The $\mathrm{N}$ from this by-product is cheaper than conventional nitrogen fertilizers and is easy to apply because it is liquid; however, little is known about its efficiency in the production of sod. Increases in dry matter production and crude protein of Brachiaria decumbens after application of OMF was observed by Schiavoni et al. (2011). The aim of this study was to evaluate the effects of liquid organo-mineral fertilizer doses and cutting thicknesses on the production of Zoysiagrass cv. Esmeralda sod.

\section{Materials and Methods}

The experiment was conducted on a sod production farm located in Capela do Alto, in the state of Sao Paulo, Brazil, from 2007 to 2010. The geographical coordinates of the area are $23^{\circ} 28^{\prime} \mathrm{S}$ and $47^{\circ} 44^{\prime} \mathrm{W}$, and the average altitude, $625 \mathrm{~m}$. Temperature and precipitation data during the experiment are presented in Figure 1.

The species selected for the study was Zoysiagrass cv. Esmeralda (Zoysia japonica Steud.), a stoloniferous, rhizomatous species. Its total area can be harvested because the subsurface rhizomes can sprout and cover the soil anew after harvest.

The soil in the area was classified as dystrophic Rhodic Hapludox (Oxisol) with a medium texture, which presented the following characteristics before the experiment was established: $\mathrm{pH}\left(\mathrm{CaCl}_{2}\right)=4.7 ; 17 \mathrm{~g} \mathrm{dm}^{-3}$ of $\mathrm{OM}^{-} 10 \mathrm{mg} \mathrm{dm}^{-3}$ of $\mathrm{P}$ (resin); 45, 0.7, 18 and $8 \mathrm{mmol}_{\mathrm{c}}$ $\mathrm{dm}^{-3}$ of $\mathrm{H}^{+}+\mathrm{Al}^{3+}, \mathrm{K}, \mathrm{Ca}$ and $\mathrm{Mg}$, respectively; and $37 \%$ base saturation. 

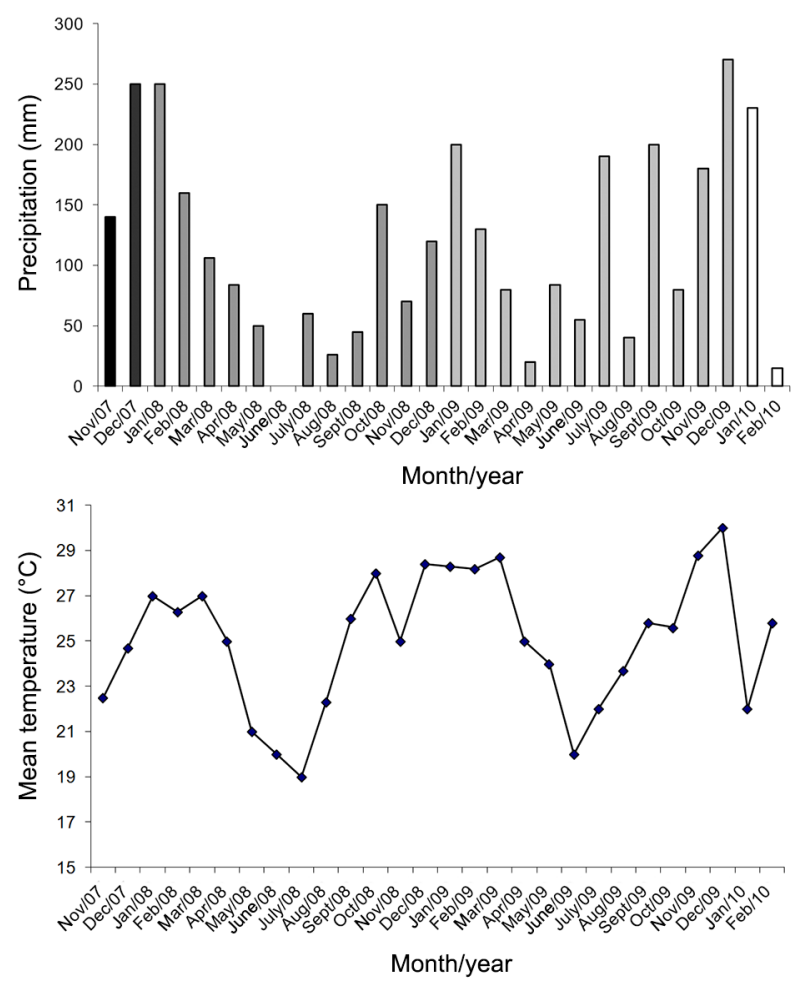

Figure 1 - Real rainfall and average air temperature in the city of Capela do Alto, SP, Brazil, from Nov 2007 to Feb 2010.

Two statistical designs were used in the experiment. The initial design consisted of randomized blocks with seven treatments and four replicates. Treatments were five doses of a liquid organo-mineral fertilizer (OMF 5-0-0) corresponding to 0, 100, 200, 300 and $400 \mathrm{~kg} \mathrm{ha}^{-1}$ of $\mathrm{N}$ with supplementation of phosphorus $(\mathrm{P})\left(80 \mathrm{~kg} \mathrm{ha}^{-1}\right.$ of $\left.\mathrm{P}_{2} \mathrm{O}_{5}\right)$ and potassium $(\mathrm{K})$ (200 kg ha-1 of $\mathrm{K}_{2} \mathrm{O}$ ). There were two control treatments, one with $300 \mathrm{~kg} \mathrm{ha}^{-1}$ of $\mathrm{N}$ as OMF and the other with $300 \mathrm{~kg} \mathrm{ha}^{-1}$ of $\mathrm{N}$ as urea supplemented by the same amount of $\mathrm{P}$ and $\mathrm{K}$ used in the treatments with OMF doses.

At harvest, a split-plot design was adopted with four replicates in a $7 \times 3$ factorial arrangement. Seven treatments were the main plots, and three sod cutting heights $(9,16$ and $22 \mathrm{~mm})$ were the subplots. Experimental plots measured $6 \times 5 \mathrm{~m}$ plus a $0.5 \mathrm{~m}$ border at each end of the plot. At harvest, these plots were reduced to a final size of $2 \times 5 \mathrm{~m}$. These parameters were used for the experiment during the second cycle.

The liquid organo-mineral fertilizer (OMF) was prepared by a controlled microbial fermentation processes in an industrial unit in Laranjal Paulista, in the state of Sao Paulo, Brazil. A fertilizer sample was analyzed as proposed by Brasil (2014). The sample presented a $\mathrm{pH}$ of 3.3 and had the following total concentrations of OM, C, N, $\mathrm{P}_{2} \mathrm{O}_{5}, \mathrm{~K}_{2} \mathrm{O}, \mathrm{Ca}$ and $\mathrm{Mg}$ : 144, 80, $50.7,1.70,6.80,0.16$ and $0.60 \mathrm{~g} \mathrm{~L}^{-1}$, respectively.
The area received an initial lime treatment with dolomitic limestone (PRNT $91 \%$ ) at $900 \mathrm{~kg} \mathrm{ha}^{-1}$ which was applied manually to the soil surface according to the base saturation required for pasture, i.e., $60 \%$. Phosphorus fertilization was carried out after liming by adding $80 \mathrm{~kg} \mathrm{ha}^{-1}$ of $\mathrm{P}_{2} \mathrm{O}_{5}$ using superphosphate as the source. OMF doses were applied with a knapsack sprayer with a constant pressure maintained by compressed $\mathrm{CO}_{2}$ at $30 \mathrm{LPF} / \mathrm{inch}^{2}$ using a bar with six nozzles spaced $0.5 \mathrm{~m}$ apart. The fertilizer was sprayed at 35,90 and 182 days after cutting (DAC) in the first cycle, and at 30, 96 and $310 \mathrm{DAC}$ in the second cycle. Urea and potassium chloride (200 kg ha ${ }^{-1} \mathrm{~K}_{2} \mathrm{O}$ ) were applied manually and split into three applications. In both cycles, the area was irrigated after the application of fertilizers to a depth of $20 \mathrm{~mm}$.

Sod was harvested mechanically by a hydraulic harvester coupled to a tractor. The area was irrigated the day before cutting, and a roller was passed over the experimental area three times to produce sod with appropriate selling characteristics. In the first cycle, the harvester was adjusted so that the sod was cut according to the thickness set for the treatments $(9,16$ and 22 $\mathrm{mm})$. For cuttings in the second cycle, the thickness that provided the highest-quality sod in the previous cycle was considered $(16 \mathrm{~mm})$. Five $0.625 \times 0.4 \mathrm{~m}$ sod samples were harvested per plot.

Percentage of ground cover (PGC), i.e., the closure of the soil with turfgrass, was assessed by digital image analysis at 90,138,197, 268, 332 and 398 DAC of the previous sod during the first cycle, and at 96, 250, 320 and $430 \mathrm{DAC}$ in the second cycle. Digital images were obtained by a 6.0 MP digital camera fixed at the end of a structure in the form of an inverted " $\mathrm{L}$ ", so that the images obtained were parallel to the surface of the turfgrass at the same height $(1.6 \mathrm{~m})$ to avoid shadows. Each photograph captured an area of approximately 2 $\mathrm{m}^{2}$. Each image was analyzed by the Corel Photo Paint software program v. 10.410 following the methodology described by Lima et al. (2010), according to which the number of pixels of a particular color could be ascertained. Thus, the PGC was determined by the selection of pixels with a green and straw color (dry turf).

At the time of the sod harvest, four "plugs", each $68 \mathrm{~mm}$ in diameter, were collected per plot with an auger sampler $(500 \mathrm{~mm}$ long, $80 \mathrm{~mm}$ in diameter, tapered at the end to $68 \mathrm{~mm}$ in diameter) to determine the dry mass. The "plugs" were washed to remove soil adhering to the material. Subsequently, leaves + stems and roots + rhizomes + stolons were separated with tweezers. Each part was dried in a convention oven for $72 \mathrm{~h}$ at 65 ${ }^{\circ} \mathrm{C}$ and subsequently weighed.

To determine tensile strength, the sod was evaluated with endurance test equipment. The procedure began by fixing the upper and lower ends of the sod samples harvested at the fixation points of the equipment. The system was tensioned with a drive crank to complete disruption of the sod samples. The force was recorded 
with a load dynamometer. These evaluations were performed on three sod samples from each replicate.

Results were subjected to analysis of variance and the $\mathrm{F}$ test at the $5 \%$ significance level as well as regression analysis; the equation with the highest $\mathrm{R}^{2}$ was chosen. Treatment means were compared using the $t$ test (LSD) at the $1 \%$ significance level. The Sisvar software program v. 4.2 was used for statistical analysis.

\section{Results and Discussion}

\section{Percentage of ground cover by turfgrass (PGC)}

In the first cycle, there was no influence of the treatments on PGC at 90 DAC ( $p>0.05)$ (Table 1). By that date, only one of the three applications of nitrogen fertilizer had been administered. The $\mathrm{N}$ reserve in the soil, roots and stolons was sufficient to provide the amount of $\mathrm{N}$ required for this early formation of turfgrass.

All the $\mathrm{N}$ had been applied by $197 \mathrm{DAC}$, and the treatments $0+(\mathrm{P}+\mathrm{K}), 100 \mathrm{~N}-\mathrm{OMF}+(\mathrm{P}+\mathrm{K})$ and $200 \mathrm{~N}$ $\mathrm{OMF}+(\mathrm{P}+\mathrm{K})$ achieved the lowest ground cover rates: 71,83 and $86 \%$, respectively. At other times (268 and $398 \mathrm{DAC})$, only treatments $0+(\mathrm{P}+\mathrm{K})$ and $100 \mathrm{~N}-\mathrm{OMF}$ $+(\mathrm{P}+\mathrm{K})$ provided coverage rates below the others due to the low amount of $\mathrm{N}$ applied.

The turfgrass that received the highest dose of $\mathrm{N}$ OMF (400 kg ha-1 N) had a $25 \%$ increase at $197 \mathrm{DAC}$, $19 \%$ at $268 \mathrm{DAC}$ and $10 \%$ at $398 \mathrm{DAC}$ in comparison with the treatment without nitrogen application. This confirms the importance of fertilization, especially $\mathrm{N}$ fertilization, to the sod formation rate. The highest PGCs rapidly obtained at $197 \mathrm{DAC}$ (91 to $94 \%$ for the doses higher than or equal to $300 \mathrm{~kg} \mathrm{ha}^{-1} \mathrm{~N}$ ) were due to good weather conditions during the period (Figure 1), which favored the growth of turfgrass. Turfgrass without nitrogen fertilization or with the $100 \mathrm{~N}-\mathrm{OMF} \mathrm{kg} \mathrm{ha}{ }^{-1}$ took longer to achieve more ground cover. The dose of 400 $\mathrm{kg} \mathrm{ha}^{-1}$ for N-OMF provided a PGC of $96 \%$ at 268 DAC. This means that the sod had nearly recovered within ap-

Table 1 - Percentage of ground cover (PGC) of Zoysiagrass cv. Esmeralda according to treatments and cutting thicknesses at 90 , 197, 268 and 398 days after the previous sod was cut during the first evaluation cycle.

\begin{tabular}{|c|c|c|c|c|}
\hline \multirow{2}{*}{ Treatments } & \multicolumn{4}{|c|}{ Time (days after the previous sod was cut) } \\
\hline & $90^{*}$ & 197 & 268 & 398 \\
\hline & & & & \\
\hline $0+(P+K)$ & 33 & $71 d$ & $78 c$ & $89 c$ \\
\hline $100 \mathrm{~N}-\mathrm{OMF}+(\mathrm{P}+\mathrm{K})$ & 37 & $83 \mathrm{c}$ & $91 b$ & $96 b$ \\
\hline $200 \mathrm{~N}-\mathrm{OMF}+(\mathrm{P}+\mathrm{K})$ & 41 & 86 bc & $94 a b$ & 99 a \\
\hline $300 \mathrm{~N}-\mathrm{OMF}+(\mathrm{P}+\mathrm{K})$ & 41 & $92 a$ & 96 a & $99 a$ \\
\hline $400 \mathrm{~N}-\mathrm{OMF}+(\mathrm{P}+\mathrm{K})$ & 47 & $93 a$ & $96 a$ & $99 a$ \\
\hline $300 \mathrm{~N}-\mathrm{OMF}$ & 39 & $91 \mathrm{ab}$ & $96 \mathrm{a}$ & $99 a$ \\
\hline $300 \mathrm{~N}$-urea $+(\mathrm{P}+\mathrm{K})$ & 33 & $94 a$ & 96 a & 99 a \\
\hline $\mathrm{CV} \%$ & 18.22 & 4.00 & 2.58 & 1.14 \\
\hline
\end{tabular}

Means followed by the same letters do not differ by the LSD test at $1 \%$; *Three applications of nitrogen fertilizer with total doses of $0,33,67,100$ and $133 \mathrm{~kg} \mathrm{ha}^{-1}$ of N-OMF (organo-mineral fertilizer) and $100 \mathrm{~kg} \mathrm{ha}^{-1}$ of N-urea. proximately 9 months. This is an important production characteristic because it allows for increased yield (four turfgrass cuttings in three years). At $300 \mathrm{~kg} \mathrm{ha}^{-1}$ of $\mathrm{N}$ $\mathrm{OMF}$, the addition of $\mathrm{P}$ and $\mathrm{K}$ provided no gains in $\mathrm{PGC}$ with results similar to those obtained with the treatment that received urea.

In the second cycle, there was an interaction between the fertilizer and cutting thicknesses for PGC at $96 \mathrm{DAC}(p \leq 0.05)$ (Table 2). At $96 \mathrm{DAC}$, one of the three applications of nitrogen fertilization was used. For the 9 mm cutting thickness, the treatment with $400 \mathrm{~N}-\mathrm{OMF}$ $\mathrm{kg} \mathrm{ha}^{-1}+(\mathrm{P}+\mathrm{K})$ provided greater ground cover than the treatment with doses lower than equal to $200 \mathrm{~kg} \mathrm{ha}^{-1}$ of $\mathrm{N}-\mathrm{OMF}$. At greater thicknesses (16 and $22 \mathrm{~mm}$ ), the 400 $\mathrm{N}-\mathrm{OMF} \mathrm{kg} \mathrm{ha}{ }^{-1}+(\mathrm{P}+\mathrm{K})$ treatment provided the highest PGC compared with the other treatments, except for the $\mathrm{N}-\mathrm{OMF}$ dose $300 \mathrm{~kg} \mathrm{ha}^{-1}$. Fertilization should be adjusted according to the thickness of the sod harvested in the previous cycle and the desired sod thickness. To achieve $56 \%$ PGC, the $15 \mathrm{~mm}$ thickness sod required a double $\mathrm{N}-\mathrm{OMF}$ dose at $96 \mathrm{DAC}$ versus the $9 \mathrm{~mm}$ sod.

When thicknesses were studied within the treatments, there was no difference except for the zero dose $(p>0.05)$ at $96 \mathrm{DAC}$ (Table 2). In the other treatments, the lowest cutting thickness provided the fastest turfgrass regrowth and a consequently higher PGC. This result was attributed to a smaller number of roots and rhizomes left in the soil when thick sod is cut (Christians, 2011).

At $250 \mathrm{DAC}$, by which time two-thirds of the $\mathrm{N}$ doses had been applied, the PGC was influenced by both treatment and cutting thickness ( $p \leq 0.05)$. However, there was no interaction between the factors. Considering only the means of treatments with fertilization, the $400 \mathrm{~N}-\mathrm{OMF} \mathrm{kg} \mathrm{ha}^{-1}+(\mathrm{P}+\mathrm{K})$ and $300 \mathrm{~N}$-urea kg ha ${ }^{-1}$ $+(\mathrm{P}+\mathrm{K})$ treatments provided higher PGC values. However, these treatments did not differ from $300 \mathrm{~N}-\mathrm{OMF}$ $\mathrm{kg} \mathrm{ha} \mathrm{h}^{-1}+(\mathrm{P}+\mathrm{K})$. The lowest thickness provided the highest PGC values. The 15 and $22 \mathrm{~mm}$ thicknesses did not differ in terms of PGC.

At the other times (320 and $430 \mathrm{DAC})$, these two factors were significant (sod thickness and $\mathrm{N}$ dose as OMF or urea, with or without supplementation of $\mathrm{P}$ and $\mathrm{K})$ without interactions $(p \leq 0.05)$. In these evaluations, Zoysiagrass cv. Esmeralda which received $300 \mathrm{~kg} \mathrm{ha}^{-1}$ of $\mathrm{N}$-OMF or more, regardless of supplementation, had a higher PGC. Turfgrass cut in the previous cycle with the highest thickness $(22 \mathrm{~mm})$ provided, slower regrowth proving that a higher removal of rhizomes and roots from the area influences sod formation time during the subsequent cycle. However, this delay can be compensated for by fertilization.

There was no influence of the N-OMF dose at the time of the first evaluation $(p>0.05)$ (90 DAC) when the turfgrass had $40 \%$ PGC. At other times, the PGC of the Zoysiagrass cv. Esmeralda was influenced by N-OMF doses $(p \leq 0.05)$ (Figure 2), similar to results reported by Lima et al. (2010) and Guertal and Evans (2006) for Ber- 
Table 2 - Percentage of ground cover (PGC) of Zoysiagrass cv. Esmeralda according to treatments and cutting thicknesses at 90, 250, 320 and 430 days after the previous sod was cut during the second evaluation cycle.

\begin{tabular}{|c|c|c|c|c|c|c|c|c|}
\hline \multirow{4}{*}{ Treatments } & \multicolumn{8}{|c|}{ Time (days after the previous sod was cut) } \\
\hline & \multicolumn{4}{|c|}{$96^{*}$} & \multicolumn{4}{|c|}{$250 * *$} \\
\hline & \multicolumn{3}{|c|}{ Thickness (mm) } & \multirow{2}{*}{ Mean } & \multicolumn{3}{|c|}{ Thickness (mm) } & \multirow{2}{*}{ Mean } \\
\hline & 9 & 16 & 22 & & 9 & 16 & 22 & \\
\hline & & & & $\%$ & & & & \\
\hline $0+(P+K)$ & $29 \mathrm{dA}$ & $30 \mathrm{eA}$ & $28 \mathrm{dA}$ & 29 & 42 & 35 & 33 & $37 d$ \\
\hline $100 \mathrm{~N}-\mathrm{OMF}+(\mathrm{P}+\mathrm{K})$ & $41 \mathrm{cA}$ & 32 de $A B$ & $29 \mathrm{cdB}$ & 34 & 50 & 40 & 37 & $42 d$ \\
\hline $200 \mathrm{~N}-\mathrm{OMF}+(\mathrm{P}+\mathrm{K})$ & $57 \mathrm{bA}$ & $41 \mathrm{cdB}$ & $32 \mathrm{cdB}$ & 43 & 62 & 54 & 49 & $55 c$ \\
\hline $300 \mathrm{~N}-\mathrm{OMF}+(\mathrm{P}+\mathrm{K})$ & $65 \mathrm{abA}$ & $47 \mathrm{bcB}$ & $35 \mathrm{cdC}$ & 49 & 71 & 62 & 55 & $63 a b$ \\
\hline $400 \mathrm{~N}-\mathrm{OMF}+(\mathrm{P}+\mathrm{K})$ & $66 \mathrm{aA}$ & $56 \mathrm{aB}$ & $47 \mathrm{aB}$ & 57 & 71 & 65 & 62 & $66 a$ \\
\hline $300 \mathrm{~N}-\mathrm{OMF}$ & $65 a b A$ & $54 \mathrm{abB}$ & $45 a b B$ & 55 & 62 & 61 & 58 & $57 \mathrm{bc}$ \\
\hline 300 N-urea $+(P+K)$ & $65 a b A$ & $44 \mathrm{cB}$ & $37 \mathrm{bcB}$ & 50 & 73 & 61 & 60 & $65 a$ \\
\hline Mean & 56 & 43 & 36 & - & $60 \mathrm{~A}$ & $54 \mathrm{~B}$ & $51 \mathrm{~B}$ & - \\
\hline CV1\% & & 13.88 & & & & & & \\
\hline CV $2 \%$ & & 17.68 & & & & & & \\
\hline \multirow{4}{*}{ Treatments } & \multicolumn{7}{|c|}{ Time (days after the previous sod was cut) } & \\
\hline & \multicolumn{4}{|c|}{320} & \multirow{2}{*}{\multicolumn{3}{|c|}{$\begin{array}{r}430 \\
\text { Thickness (mm) }\end{array}$}} & \\
\hline & \multicolumn{3}{|c|}{ Thickness (mm) } & & & & & \multirow{2}{*}{ Mean } \\
\hline & 9 & 16 & 22 & Mean & 9 & 16 & 22 & \\
\hline & & & & $\%$ & 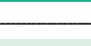 & & & \\
\hline $0+(P+K)$ & 48 & 44 & 43 & $45 d$ & 71 & 70 & 66 & $69 \mathrm{~d}$ \\
\hline $100 \mathrm{~N}-\mathrm{OMF}+(\mathrm{P}+\mathrm{K})$ & 76 & 75 & 67 & $73 c$ & 85 & 84 & 76 & $81 \mathrm{c}$ \\
\hline $200 \mathrm{~N}-\mathrm{OMF}+(\mathrm{P}+\mathrm{K})$ & 80 & 86 & 81 & $86 b$ & 94 & 91 & 91 & $92 b$ \\
\hline $300 \mathrm{~N}-\mathrm{OMF}+(\mathrm{P}+\mathrm{K})$ & 93 & 92 & 90 & $92 \mathrm{a}$ & 99 & 96 & 95 & $97 a$ \\
\hline $400 \mathrm{~N}-\mathrm{OMF}+(\mathrm{P}+\mathrm{K})$ & 96 & 92 & 92 & $94 \mathrm{a}$ & 98 & 96 & 95 & $97 a$ \\
\hline 300 N-OMF & 94 & 93 & 92 & $93 a$ & 97 & 97 & 95 & $96 a$ \\
\hline 300 N-urea $+(P+K)$ & 96 & 94 & 91 & $93 a$ & 98 & 96 & 94 & $96 \mathrm{a}$ \\
\hline Mean & $85 \mathrm{~A}$ & $82 \mathrm{~B}$ & $80 \mathrm{C}$ & - & $92 \mathrm{~A}$ & $90 \mathrm{~B}$ & $87 \mathrm{C}$ & - \\
\hline CV1\% & \multicolumn{4}{|c|}{4.42} & \multicolumn{4}{|c|}{3.12} \\
\hline CV2\% & \multicolumn{4}{|c|}{3.62} & \multicolumn{4}{|c|}{2.87} \\
\hline
\end{tabular}

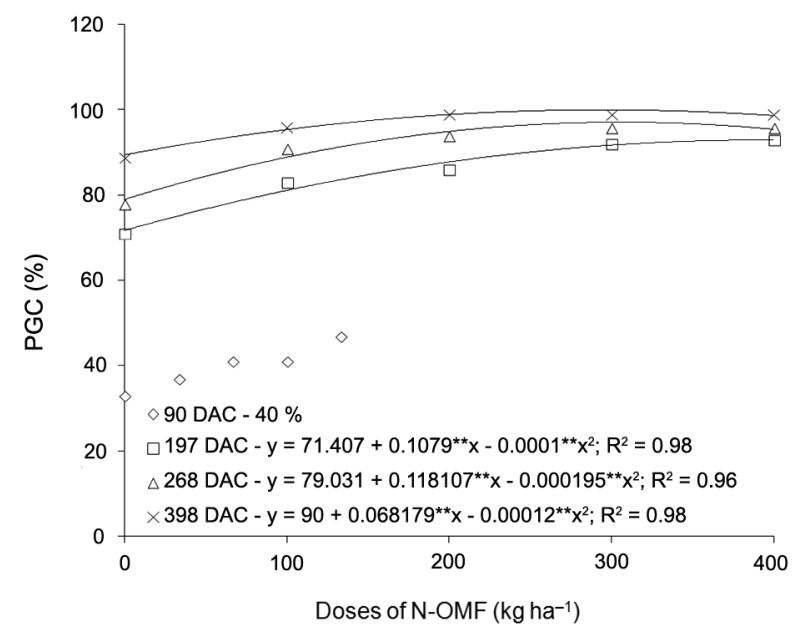

Figure 2 - Percentage of ground cover (PGC) of Zoysiagrass cv. Esmeralda according to doses of N-OMF at 90, 197, 268 and 398 days after cutting (DAC) in the first evaluation cycle. * * Significant by the t-test at $1 \%$. mudagrass cv. Celebration and the hybrid Bermudagrass cv. TifEagle, respectively.

Although the quadratic model had been adjusted for PGC as a function of N-OMF doses at 197 DAC, the highest coverage rate (93\%) was obtained with these doses. PGC increased with doses up to $400 \mathrm{~kg} \mathrm{ha}^{-1}$ of $\mathrm{N}-\mathrm{OMF}$ for this evaluation.

The maximum percentage of ground cover were obtained at 303 and $284 \mathrm{~kg} \mathrm{ha}^{-1}$ of N-OMF at 268 and 398 DAC, respectively, after doses were adjusted according to the equations. Doses above $300 \mathrm{~kg} \mathrm{ha}^{-1} \mathrm{~N}$-OMF did not increase the PGC of Zoisiagrass cv. Esmeralda. Inorganic fertilizers applied at 200-300 $\mathrm{kg} \mathrm{ha}^{-1} \mathrm{~N}$ were adequate for turfgrass (Cynodon dactylon L.) and sod production (Barton et al., 2006). For the state of Florida, USA, 200 to 280 $\mathrm{kg} \mathrm{ha}^{-1} \mathrm{~N}$ is recommended for sod production from Zoysiagrass (Sartain, 2007). Excessive doses may force shoot growth leading to an increased number of cuts (clippings) over the root system, rhizome and/or stolon growth. This reduces sod liftability after harvest (Carrow et al., 2001).

An N-urea dose of $365 \mathrm{~kg} \mathrm{ha}^{-1}$, split into three applications, produced Bermudagrass sods resistant to handling in 6 months (Lima et al., 2010). In this experi- 
ment, the N-OMF dose of $303 \mathrm{~kg} \mathrm{ha}^{-1}$ (Figure 2) provided almost full closure of Zoysiagrass cv. Esmeralda sod in 9 months (268 DAC). Experimental variations are related to doses, climatic conditions, irrigation, soil type and thickness of the sod harvested during the last cycle. The time required to produce a marketable crop of sod varies from 3 months, in more favorable climates, to 2 years, under less favorable conditions (Cockerham, 2008).

In the second cycle, there was an interaction between N-OMF doses and the cutting thicknesses on the PGC ( $p \leq 0.05)$ as evaluated at 96 DAC (Figure 3A). For the $9 \mathrm{~mm}$ thickness, there was a quadratic adjustment and $400 \mathrm{~kg} \mathrm{ha}^{-1}$ of N-OMF provided the highest PGC. For other thicknesses, the cover rates were adjusted linearly to the $\mathrm{N}-\mathrm{OMF}$ doses with an increase in PGC and an increase in doses. The coefficients of adjusted linear equations for the cutting thicknesses showed that the PGC of the soil increased by approximately 14, 20 and $54 \%$ per $100 \mathrm{~kg} \mathrm{ha}^{-1}$ of N-OMF when applied to the thicknesses of 22, 16 and 9 $\mathrm{mm}$ (Figure 3A). Thus, thinner sod (up to $9 \mathrm{~mm}$ ) had more roots and rhizomes remaining in the soil and the greatest increase in PGC as a function of N-OMF dose.

At other times, there were no significant interactions between sod thickness and $\mathrm{N}$ dose applied as OMF or urea, with or without $\mathrm{P}$ and $\mathrm{K}$ supplementation (Figure 3B). At $250 \mathrm{DAC}$, there was a linear adjustment in the increase in PGC with dose increases. The maximum PGC achieved at this time was $60 \%$ for the treatment with 400 $\mathrm{kg} \mathrm{ha}^{-1}$ of N-OMF. At the other points in time, the adjustment was quadratic. The N-OMF doses of 350 and $392 \mathrm{~kg}$ $\mathrm{ha}^{-1}$ provided the maximum PGC of the turfgrass (95 and $100 \%)$ at 320 and $430 \mathrm{DAC}$, respectively. At $430 \mathrm{DAC}$, there was a $28 \%$ increase in the PGC of the treatment that received $400 \mathrm{~kg} \mathrm{ha}^{-1}$ in relation to the treatment that received no nitrogen fertilization.

\section{Dry matter}

Leaves and stems were only affected by fertilization and not by sod thickness during the two cycles evaluated (Table 3). Maximum dry matter was obtained when $400 \mathrm{~kg} \mathrm{ha}{ }^{-1} \mathrm{~N}-\mathrm{OMF}+(\mathrm{P}+\mathrm{K})$ was applied. However, it was not different from the treatments that received 300 $\mathrm{kg} \mathrm{ha}^{-1} \mathrm{~N}$ through OMF or urea during the first cycle. In the second cycle, the highest N-OMF dose also provided the highest yield of leaves + stem. However, it was no different from the treatment that received $300 \mathrm{~kg} \mathrm{ha}^{-1}$ of $\mathrm{N}-\mathrm{OMF}$ with supplementation of $\mathrm{P}$ and $\mathrm{K}$. A higher number of leaves does not imply better-quality sod, because excess $\mathrm{N}$ may lead to less formation of the root system, rhizome and/or stolons. This consequently leads to lower liftability and may reduce yield (Tesfamariam et al., 2009; Lima et al., 2010; Christians, 2011). The same effect could be observed in this experiment in which the dry matter of stolons + rhizomes in the treatment with $400 \mathrm{~kg} \mathrm{ha}^{-1}$ of $\mathrm{N}-\mathrm{OMF}+(\mathrm{P}+\mathrm{K})$ was lower than that obtained in the treatment with $300 \mathrm{~kg} \mathrm{ha}^{-1}$ of $\mathrm{N}-\mathrm{OMF}+(\mathrm{P}+\mathrm{K})$.

In the first cycle, there was an influence of both fertilization and sod thickness $(p \leq 0.05)$ on the dry matter of stolons + rhizomes and roots, with no interactions between these sources of variation. For stolons + rhizomes and roots, the treatments that provided the lowest accumulations were $0(\mathrm{P}+\mathrm{K})$ and $300 \mathrm{~N}-\mathrm{OMF}$ (Table 3). Omission of $\mathrm{P}$ and $\mathrm{K}$ limited the growth of stolons, rhizomes and roots in the treatment that received only $\mathrm{N}-\mathrm{OMF}$, this indicates the importance of $\mathrm{P}$ and $\mathrm{K}$ for the formation of the plant parts that provide tensile strength to sods. Despite having $\mathrm{P}$ and $\mathrm{K}$ in its formulation, the OMF used here is not sufficient for the demands of Zoysiagrass sod production, and thus supplementation is needed.

OMF application in the soil cultivated with Brachiaria brizantha cv. Xaraés influenced the $\mathrm{P}$ content in the soil only in the $0-0.1 \mathrm{~m}$ soil layer (Heinrichs et al., 2012). The importance of $\mathrm{P}$ to root growth is wellknown, and turfgrass grown in soils deficient in $\mathrm{P}$ cannot produce a well-developed root system /Christians,

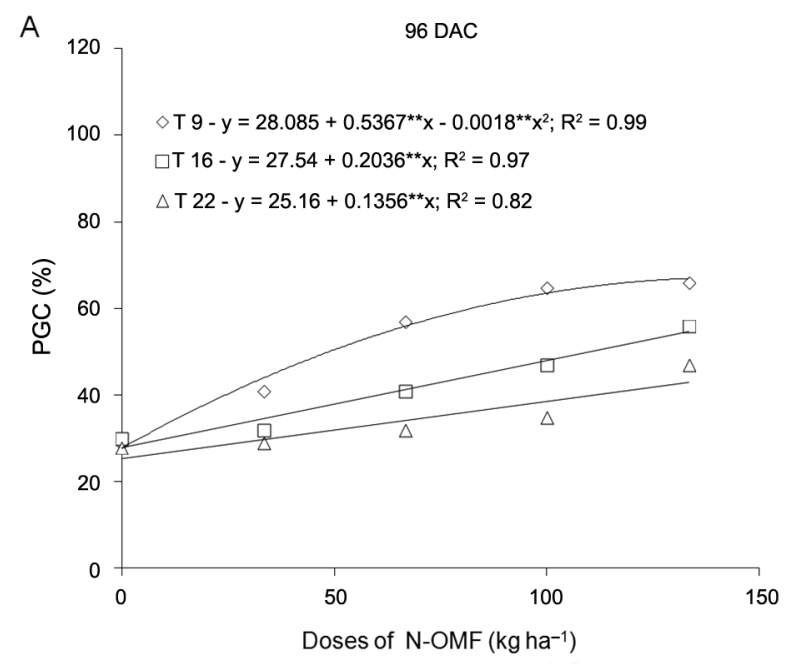

B

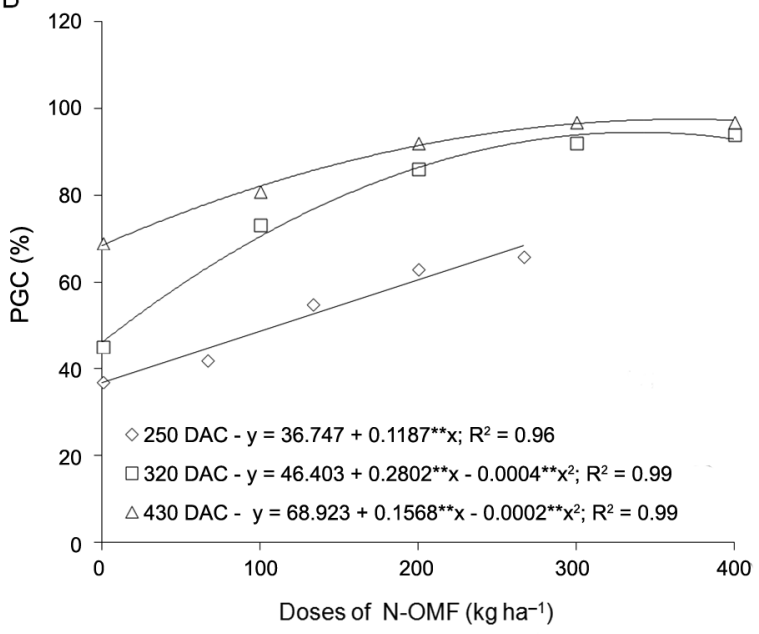

Figure 3 - Percentage of ground cover (PGC) of Zoysiagrass cv. Esmeralda according to N-OMF doses and cutting thicknesses at 96 days after cutting (DAC) (A) and as a function of N-OMF doses at 250, 320 and 430 DAC (B) in the second evaluation cycle. ${ }^{*}$ Significant by the t-test at $1 \%$. 
Table 3 - Dry matter of leaf + stem, rhizome + stolon and roots of Zoysiagrass cv. Esmeralda according to treatments in the first and second cycles (Capela do Alto, SP, Brazil, 2007-2010).

\begin{tabular}{|c|c|c|c|c|c|c|c|c|c|}
\hline \multicolumn{10}{|c|}{$1^{\text {st }}$ cycle } \\
\hline \multirow{4}{*}{ Treatments } & \multicolumn{9}{|c|}{ Dry matter } \\
\hline & Leaf+stem & \multicolumn{4}{|c|}{ Rhizome+stolons } & \multicolumn{4}{|c|}{ Root } \\
\hline & \multirow{2}{*}{ Mean } & \multicolumn{3}{|c|}{ Thickness (mm) } & \multirow{2}{*}{ Mean } & \multicolumn{3}{|c|}{ Thickness (mm) } & \multirow{2}{*}{ Mean } \\
\hline & & 9 & 16 & 22 & & 9 & 16 & 22 & \\
\hline & & & & & $-\mathrm{kg} \mathrm{ha}^{-1}$ & & & & \\
\hline $0^{1}$ & $3544 d$ & 3637 & 4056 & 4287 & 3993 c & 583 & 610 & 853 & $682 c$ \\
\hline 100 N-OMF $^{1}$ & $5549 c$ & 4361 & 4706 & 5028 & $4698 b$ & 642 & 707 & 845 & $731 b c$ \\
\hline $200 \mathrm{~N}^{-O M F}{ }^{1}$ & 6060 bc & 4929 & 4908 & 5027 & $4955 b$ & 713 & 820 & 923 & 819 a \\
\hline 300 N-OMF$^{1}$ & $6413 a b$ & 5284 & 5598 & 5898 & 5593 a & 742 & 822 & 958 & $840 \mathrm{a}$ \\
\hline 400 N-OMF $^{1}$ & $6867 a$ & 4740 & 4856 & 5027 & $4894 b$ & 728 & 797 & 845 & $790 a b$ \\
\hline 300 N-OMF$^{2}$ & $6391 a b$ & 3786 & 4444 & 4540 & $4256 c$ & 584 & 766 & 760 & $704 c$ \\
\hline 300 N-Urea $^{1}$ & $6497 a b$ & 5389 & 5523 & 5864 & 5592 a & 729 & 818 & 972 & $840 \mathrm{a}$ \\
\hline Mean & - & $4598 \mathrm{~b}$ & $4869 a$ & $5096 a$ & - & $674 c$ & $763 b$ & $880 \mathrm{a}$ & - \\
\hline CV1\% & 14.87 & \multicolumn{4}{|c|}{9.14} & \multicolumn{4}{|c|}{9.33} \\
\hline CV2\% & 13.83 & \multicolumn{4}{|c|}{8.64} & \multicolumn{4}{|c|}{8.04} \\
\hline \multicolumn{10}{|c|}{$2^{\text {nd }}$ cycle } \\
\hline \multirow{4}{*}{ Treatments } & \multicolumn{9}{|c|}{ Dry matter } \\
\hline & Leaf+stem & \multicolumn{4}{|c|}{ Rhizome+stolons } & \multicolumn{4}{|c|}{ Root } \\
\hline & \multirow{2}{*}{ Mean } & \multicolumn{3}{|c|}{ Thickness (mm) } & & \multicolumn{3}{|c|}{ Thickness (mm) } & \multirow{2}{*}{ Mean } \\
\hline & & 9 & 16 & 22 & Mean & 9 & 16 & 22 & \\
\hline & & & & & - $\mathrm{kg} \mathrm{ha}^{-1}$ & & & & \\
\hline $0^{1}$ & $5407 d$ & 5815 & 5733 & 5476 & 5674 e & 1006 & 1005 & 982 & $998 \mathrm{e}$ \\
\hline 100 N-OMF $^{1}$ & $6241 c$ & 6786 & 6643 & 6610 & $6680 \mathrm{c}$ & 1257 & 1194 & 1138 & $1196 \mathrm{~d}$ \\
\hline 200 N-OMF$^{1}$ & $6425 c$ & 7055 & 6884 & 6812 & 6917 c & 1304 & 1360 & 1344 & 1336 bc \\
\hline 300 N-OMF $^{1}$ & $7002 a b$ & 8324 & 8235 & 8306 & 8288 a & 1491 & 1453 & 1451 & 1465 a \\
\hline 400 N-OMF $^{1}$ & 7320 a & 6727 & 6782 & 6568 & $6692 \mathrm{~cd}$ & 1279 & 1152 & 1212 & $1214 \mathrm{~cd}$ \\
\hline 300 N-OMF² & $6422 c$ & 6450 & 6266 & 6183 & $6299 \mathrm{~d}$ & 1138 & 1154 & 1110 & $1134 d$ \\
\hline 300 N-Urea $^{1}$ & $6731 \mathrm{bc}$ & 7950 & 7932 & 7701 & $7861 \mathrm{~b}$ & 1378 & 1392 & 1305 & $1358 \mathrm{ab}$ \\
\hline Mean & - & 7015 & 6925 & 6808 & - & 1265 & 1244 & 1220 & - \\
\hline$\overline{\mathrm{CV} 1 \%}$ & 8.90 & \multicolumn{4}{|c|}{6.39} & \multicolumn{4}{|c|}{11.93} \\
\hline $\mathrm{CV} 2 \%$ & 10.41 & \multicolumn{4}{|c|}{6.19} & \multicolumn{4}{|c|}{17.01} \\
\hline
\end{tabular}

2011). Therefore, the response of turfgrass to the application of $\mathrm{P}$ depends on the $\mathrm{P}$ content available in the soil. In this case, the $\mathrm{P}$ content was very low $10 \mathrm{mg}$ $\mathrm{dm}^{-1}$, resin extractor).

Because of the lower sod cutting thickness in the first cycle, fewer stolons and rhizomes were removed (Table 3). There was no difference between the thicknesses of 16 and $22 \mathrm{~mm}$ in relation to these sod structures; however, the highest sod thickness adversely affected sprouting in the subsequent cycle as noted by PGC at 430 DAC in the second cycle (Table 2).

In the second cycle, there was an influence on fertilization $(p<0.05)$ at a dose of only $300 \mathrm{~kg} \mathrm{ha}^{-1}$ of N-OMF plus supplementation with $\mathrm{P}$ and $\mathrm{K}$. This provides greater accumulation of stolons + rhizomes and roots. Comparing the amount of accumulated rhizomes and stolons in this cycle with the previous cycle, there was an increase of more than $2,000 \mathrm{~kg} \mathrm{ha}^{-1}$ perhaps due to the long formation of sods during this cycle of 15 months.

When only N-OMF doses were considered during the first cycle, the dry matter of leaves + stems adjusted quadratically to the doses. According to the equation, the maximum dry matter $\left(6,756 \mathrm{~kg} \mathrm{ha}^{-1}\right)$ was achieved at
$361 \mathrm{~kg} \mathrm{ha}^{-1}$. In the second cycle, there was an increasing linear adjustment: higher dry weights were obtained as $\mathrm{N}-\mathrm{OMF}$ doses were increased (Figure 4).

For the dry matter of stolons + rhizomes and roots, there was a quadratic adjustment in both cycles. According to the equations, the maximum values for rhizomes + stolons were obtained with 278 and $264 \mathrm{~kg} \mathrm{ha}^{-1}$ of N-OMF in the first and second cycles, respectively. The N-OMF doses of 285 and $252 \mathrm{~kg} \mathrm{ha}^{-1}$ provided maximum root response (Figure 4).

The doses that provided the greatest amount of dry matter of stolons + rhizomes and roots were lower than the dose that yielded the largest leaf + stem dry matter. The production of stolons, rhizomes and roots is the most important factor for the production of turfgrass because these are the parts (organs) that provide a more robust sod structure with greater tensile strength to facilitate sod handling (Christians, 2011). The doses calculated for completing the sod formation can be adjusted to the doses necessary to produce a greater amount of these structures. Thus, $278 \mathrm{~kg} \mathrm{ha}^{-1}$ provided the maximum amount of stolons + rhizomes and may be adequate for the production of high-quality Zoysiagrass cv. Esmeralda sods. 

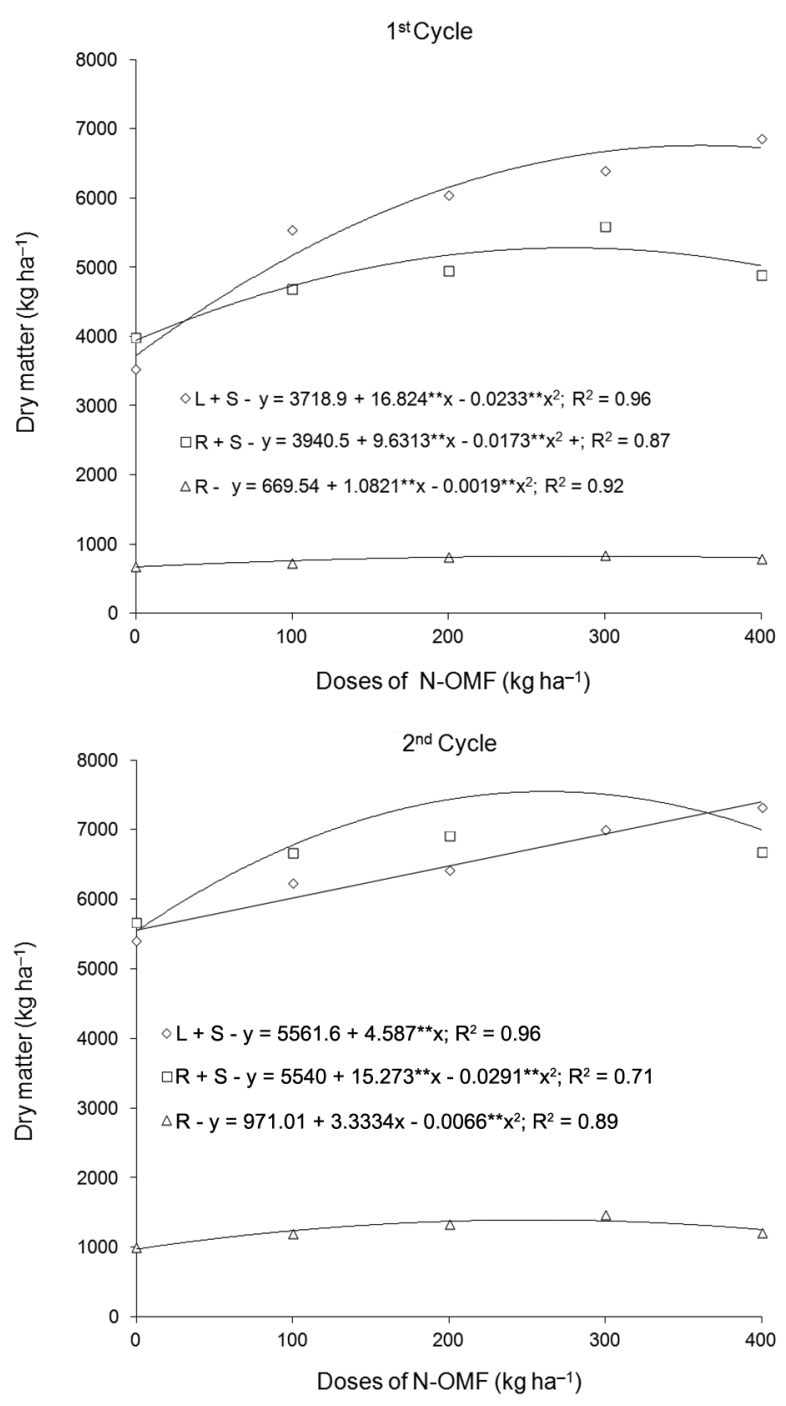

Figure 4 - Dry matter of leaf + stem $(L+S)$, rhizome + stolon $(R+S)$ and root (R) of Zoysiagrass cv. Esmeralda according to N-OMF doses in the first and second cycles. ${ }^{*}$ Significant by the t-test at $1 \%$.
Higher doses of $\mathrm{N}$ may cause a decrease in rhizome and root production and an increase in the production of leaves + stems. This is unfavorable because it increases the demand for cutting leaves (clipping) and raises the cost of production (Quiroga-Garza et al., 2001). The removal of clippings also depletes turfgrass carbohydrate reserves that may be needed during periods of stress (Qian and Fry, 1996). The dry weight of stolons and rhizomes of the hybrid bermudagrass decreased as the $\mathrm{N}$ rate was increased (Guertal and Hicks, 2009).

\section{Tensile strength of sods}

In the first cycle, fertilization and thicknesses influenced the tensile strength of the sod samples ( $p \leq 0.05)$. There was no interaction between treatments (Table 4). The $300 \mathrm{~N}$-urea $+(\mathrm{P}+\mathrm{K})$ sample had the highest tensile strength followed by the treatment with $300 \mathrm{~N}-\mathrm{OMF}+$ $(\mathrm{P}+\mathrm{K})$. Thinner sods had lower tensile strength.

In the second cycle, only fertilization $(p \leq 0.05)$ influenced tensile strength (Table 4). The effect of the sod thickness was not maintained in the second cycle.

The highest tensile strength of Zoysiagrass cv. Esmeralda sods was obtained with the treatment that received $300 \mathrm{~kg} \mathrm{ha}^{-1}$ of $\mathrm{N}$ (regardless of the source used) plus supplementation with $\mathrm{P}$ and $\mathrm{K}$. The highest production of stolons, rhizomes and roots was obtained with this treatment. This proves that the tensile strength of the sods is directly related to increased production of such structures. The treatments that provided the lowest tensile strength were those that did not receive $\mathrm{N}$ and did not form sods as well as those that received only $\mathrm{N}$ without $\mathrm{P}$ and $\mathrm{K}$.

There was a quadratic adjustment of the sod tensile strength to N-OMF doses as evaluated on the two dates (Figure 5). The maximum tensile strength values (36 and $45 \mathrm{kgf}$ ) were obtained with 265 and $254 \mathrm{~kg} \mathrm{ha}^{-1}$ in the first and second cycles, respectively. Higher $\mathrm{N}$ doses resulted in lower tensile strength due to a higher growth of leaves over stolons, rhizomes and roots (Figure 4). At the zero dose, tensile strength was lower because the sods had not yet formed. Nitrogen doses above $365 \mathrm{~kg} \mathrm{ha}^{-1}$ decreased the tensile strength of Bermuda-grass sods (Cynodon dac-

Table 4 - Tensile strength of Zoysiagrass cv. Esmeralda sods according to the treatments evaluated over the two cycles.

\begin{tabular}{|c|c|c|c|c|c|c|c|c|}
\hline \multirow{3}{*}{ Treatments } & \multicolumn{4}{|c|}{$1^{\text {st }}$ cycle } & \multicolumn{4}{|c|}{$2^{\text {nd }}$ cycle } \\
\hline & \multicolumn{3}{|c|}{ Thicknesses (mm) } & \multirow{2}{*}{ Mean } & \multicolumn{3}{|c|}{ Thicknesses (mm) } & \multirow{2}{*}{ Mean } \\
\hline & 9 & 16 & 22 & & 9 & 16 & 22 & \\
\hline $0(P+K)$ & 14.3 & 18.6 & 21.9 & $18.3 \mathrm{f}$ & 27.0 & 27.7 & 31.2 & $28.7 \mathrm{c}$ \\
\hline $100 \mathrm{~N}-\mathrm{OMF}+(\mathrm{P}+\mathrm{K})$ & 23.8 & 27.2 & 31.1 & $27.4 \mathrm{e}$ & 38.2 & 40.0 & 42.0 & $40.0 \mathrm{ab}$ \\
\hline $200 \mathrm{~N}-\mathrm{OMF}+(\mathrm{P}+\mathrm{K})$ & 28.1 & 33.3 & 34.4 & $31.9 \mathrm{c}$ & 41.0 & 43.7 & 44.2 & $43.0 \mathrm{ab}$ \\
\hline $300 \mathrm{~N}-\mathrm{OMF}+(\mathrm{P}+\mathrm{K})$ & 35.4 & 39.1 & 39.3 & $39.7 \mathrm{~b}$ & 45.5 & 46.0 & 46.5 & $46.0 \mathrm{a}$ \\
\hline $400 \mathrm{~N}-\mathrm{OMF}+(\mathrm{P}+\mathrm{K})$ & 26.8 & 30.0 & 30.5 & $29.1 \mathrm{de}$ & 37.7 & 40.0 & 40.7 & $39.5 a b$ \\
\hline $300 \mathrm{~N}-\mathrm{OMF}$ & 28.9 & 31.4 & 32.9 & $31.1 \mathrm{~cd}$ & 35.0 & 36.0 & 38.5 & $36.5 \mathrm{bc}$ \\
\hline $300 \mathrm{~N}$-urea + $(\mathrm{P}+\mathrm{K})$ & 38.8 & 40.8 & 43.2 & $40.9 a$ & 42.7 & 46.7 & 47.5 & $45.7 \mathrm{a}$ \\
\hline Mean & $28.0 \mathrm{c}$ & $31.5 \mathrm{~b}$ & $33.3 \mathrm{a}$ & - & 38.2 & 40.0 & 41.5 & - \\
\hline CV1\% & \multicolumn{4}{|c|}{10.38} & \multicolumn{4}{|c|}{25.46} \\
\hline CV2\% & \multicolumn{4}{|c|}{8.79} & \multicolumn{4}{|c|}{23.06} \\
\hline
\end{tabular}

$\mathrm{OMF}=$ organo-mineral fertilizer; Means followed by the same letters do not differ by the LSD test at $1 \%$. 


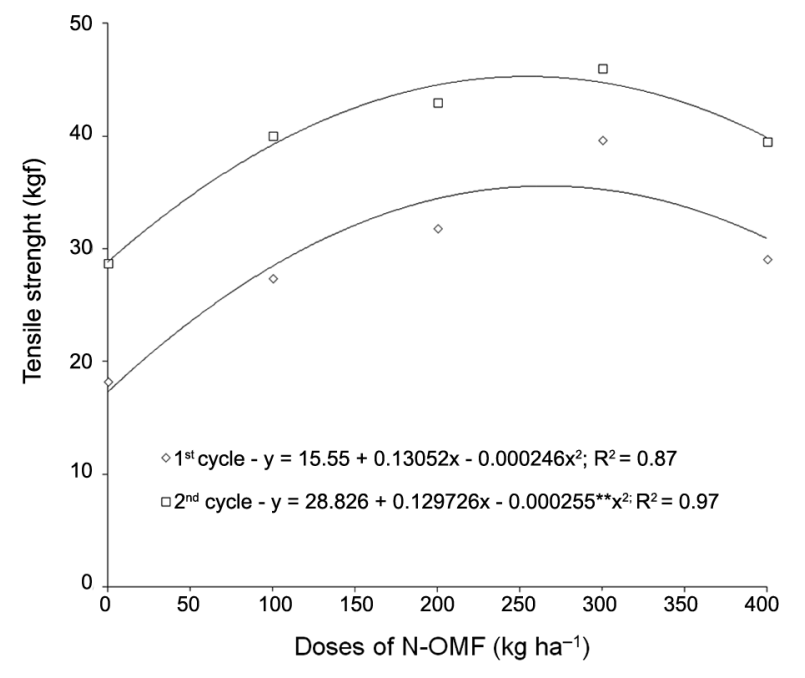

Figure 5 - Tensile strength of Zoysiagrass cv. Esmeralda sods according to N-OMF doses in the first and second cycles. ** Significant by the test $t$ at $1 \%$.

tylon L), which reduced their yield (Lima et al., 2010). The total dose of nitrogen applied during the growing season is one of the main factors that influence the tensile strength of Kentucky bluegrass (Poa pratensis L.) sod, in clayey soils (Deying et al., 2011).

The difference between the dose that provided the maximum dry matter production of stolons and rhizomes and the dose that provided the greatest sod tensile strength was $13 \mathrm{~kg} \mathrm{ha}^{-1}$ of $\mathrm{N}$ in the first cycle and $31 \mathrm{~kg}$ $\mathrm{ha}^{-1}$ of $\mathrm{N}$ in the second cycle.

\section{Conclusions}

OMF influenced the percentage of ground cover of Zoysiagrass cv. Esmeralda in both cycles. The $\mathrm{N}$ dose of $300 \mathrm{~kg} \mathrm{ha}^{-1}$ provided the fastest turfgrass closure and the greatest mass of roots, rhizomes and stolons. Consequently, this treatment provided the greatest tensile strength. Thinner sods had faster regrowth because more roots had remained in the soil.

Fertilization should be adjusted according to the thickness of the sod previously harvested or when a higher rate of sod formation is desired. Absence of phosphorus and potassium fertilization decreased the dry matter of stolons and rhizomes and consequently produced sod with lower tensile strength in both cycles.

\section{References}

Barton, L.; Wan, G.G.Y.; Colmer, T.D. 2006. Turfgrass (Cynodon dactylon L.) sod production on sandy soils. I. Effects of irrigation and fertilizer regimes on growth and quality. Plant and Soil 284: 129-145.

Bowman, D.C.; Cherney, C.T.; Rufty Junior, T.W. 2002. Fate and transport of nitrogen applied to six warm-season turfgrasses. Crop Science 24: 833-841.
Brasil. Ministério da Agricultura, Pecuária e Abastecimento [MAPA]. 2014. Manual of Official Analytical Methods for Fertilizers and Liming Materials = Manual de Métodos Analíticos Oficiais para Fertilizantes e Corretivos. MAPA/SDA/CGAL, Brasília, DF, Brazil (in Portuguese).

Christians, N.E. 2011. Fundamentals of Turfgrass Management. 4ed. John Willey, Hoboken, NJ, USA.

Cockerham, C.T. 2008. Turfgrass culture for sod production. p. 139150. In: Pessarakli, M., ed. Handbook of turfgrass management and physiology. CRC Press, Boca Raton, FL, USA.

Dinalli, R.P.; Buzetti, S.; Gazola, R.N.; Castilho, R.M.M.; Celestrino, T.S.; Dupas, E.; Teixeira Filho, M.C.M.; Lima, R.C. 2015. Application of herbicides as growth regulators of emerald Zoysia grass fertilized with nitrogen. Semina: Ciências Agrárias 36: 1875-189.

Deying, L.; Fang, W.; Han, L. 2011. Nitrogen fertilization influences shear strength and quality Kentucky bluegrass sod grown on clay. Agronomy Journal 103: 751-755.

Gazola, R.P.D.; Buzetti, S.; Gazola, R.N.; Castilho, R.M.M.; Teixeira Filho, M.C.M.; Celestrino, T.S.; Dupas, E. 2016. Nitrogen dose and type of herbicide used for growth regulation on the green coloration intensity of Emerald grass. Ciência Rural 46: 990.

Guertal, E.A.; Evans, D.L. 2006. Nitrogen rate and mowing height effects on Tifeagle bermudagrass establishment. Crop Science 46: $1772-1778$.

Guertal, E.A.; Hicks, C.A. 2009. Nitrogen source and rate effects on the establishment of 'TifSport' and 'Tifway' hybrid bermudagrass. Crop Science 49: 690-695.

Falconer, L.; Niemeyer, M. 2006. Economic analysis, impact and agronomic profile of sod production in Texas. Available at: http:// www.txsod.com/docs/ecoanaylasisrpt.pdf [Accessed Mar 19, 2016]

Heinrichs, R.; Soares Filho, C.V.; Crociolli, C.A.; Figueiredo, P.A.M.; Fruchi, V.M.; Kodel, F.J.; Rodrigues, T.A. 2012. Doses and sources of nitrogen fertilizer and their effects on soil chemical properties and forage yield of Brachiaria brizantha cv. Xaraés. Semina: Ciências Agrárias 33: 1745-1754 (in Portuguese, with abstract in English).

Lima, C.P.; Backes, C.; Villas Bôas, R.L.; Oliveira, M.R.; Kiihl, T.A.M.; Freitag, E.E. 2010. Bermudagrass sod production as related to nitrogen rates. Revista Brasileira de Ciência do Solo 34: 371-378.

Qian, Y.L.; Fry, J.D. 1996. Irrigation frequency affects Zoysia grass rooting and plant water status. HortScience 31: 243-247.

Quiroga-Garza, H.M.; Picchioni, G.A.; Remmenga, M.D. 2001. Bermuda grass fertilized with slow-release nitrogen sources. I. Nitrogen uptake and potential leaching losses. Journal of Environmental Quality 30: 440-448.

Sartain, J.B. 2007. Fertility considerations for sod production. SL-52. Cooperative Extension Service, University of Florida, Gainesville, FL, USA.

Schiavoni, E.A.; Alves, M.C.; Souza, Z.M.; Costa, F.G. 2011. Influence of organic-mineral fertilization of an Oxisol on soil chemical properties and Bracharia brizantha production. Revista Brasileira de Ciência do Solo 35: 2219-2226.

Tesfamariam, E.H.; Annandale, J.G.; Steyn, J.M. 2009. Exporting large volumes of municipal sewage sludge through turfgrass sod production. Journal of Environmental Quality 38: 1320-1328. 